Milan Skakun, Goran Jević, Jelena Jević

The College of Tourism, Belgrade, Serbia

UDC 378:338.48(497.11)

\title{
LAW IN ACCREDITED TOURISM CURRICULA AT HIGHER EDUCATION INSTITUTIONS IN SERBIA
}

\begin{abstract}
Tourism is relatively new but still a very complex industry, which creates the necessity for legal regulations of different relations in tourism. Quite often, the relations are completely new to the existing legislation and legal practice. On the other hand, it is relatively easy to find appropriate examples for many of them in existing law of obligations, ownership, civil and other laws. The course of Law in Tourism is necessary for educating and training students in order to introduce them to legal disciplines and institutions regulating social relations relevant to tourism industry. It includes relations between a company (entrepreneurs) and the state, relations between companies in tourism industry and tourism service sector and agents with the direct user - a tourist. The aim of this paper is to attempt to present the updated situation of law
\end{abstract}

\section{Introduction}

Working in tourism since the very beginning of the so-called "mass tourism" has included humans as the key factor, which quite often tipped the scales when choosing a destination. Today, there is an assumption that online reservation, more and more present in contemporary tourism, endan- courses by analysing curricula of tourism colleges and faculties in Serbia. Methodology used for data collection is based on desk research with national and international references, mostly from tourism field. Comparison and analysis were mostly used in data processing. The paper consists of two parts. The first part is entitled 'Defining Tourism and Law in Tourism' and the second is 'Representation of Law Courses in Accredited Tourism Curricula at Higher Education Institutions in Serbia'.

Based on the curriculum and sylabus analysis of tourism higher education institutions, it can be concluded that law courses are inadequately represented with a total of only $3.8 \%$.

Key words: tourism, law in tourism, accredited curricula

gered the survival of travel agencies, but this is only one segment of the tourism industry. Therefore, there is still the rule that tourism professionals are required to have a wider education, but also certain knowledge. One of them is familiarity with legal regulations in tourism industry, especially now when Serbia has adapted its legislation in line with the common law of the EU. 


\section{Defining tourism and law in tourism}

Tourism?! It is a word often heard in every-day conversation. And is it the term that everyone can define? For a tourist, it denotes carefree days filled with relaxation and enjoyment. For the staff in agencies, hotels, transportation companies it means work, source of income, existence. For the state, it is the branch of industry earning foreign exchange, filling up the budget. For the researchers of this omni-present phenomenon, it has also different meanings depending on the aspect of study. For instance, Blagojević (2010: 18) considers that the universal definition of tourism connects more concepts, factors and elements and he quotes Swiss authors Hunziker and Krapf, which was also adopted by International Association of Scientific Experts in Tourism (AIEST) according to which "tourism is a set of relations and phenomena resulting from visitors' travel to and stay in a place, if the stay is not a permanent residence and if the travel does not involve a business activity". According to Vukonić (2010: 15), this definition excellently reflects the notion of tourism among the researchers, as well as the conditions in which tourism is developed and understood by wider public. It is evident that a tourist, i.e. a visitor, is placed in the focus, whereas the other part of the phenomenon, the tourist offer, is mentioned in general terms. Vukonić (2010: 21) further quotes the definition of tourism given by the World Tourism Organisation in 1995: “Tourism comprises activities of persons travelling to or staying at places outside their residence for a period not longer than a consequtive year for leisure, business or other reasons". At first glance, there is a great difference between all other definitions of tourism which made the distinction between profitable travel and tourist travel. This definition overcomes the mentioned differences, which can be explained by statistical reasons. However, in order to maintain the main postulates of tourism theory and to stay protected from potential criticism, WTO has separated two categories: travellers and visitors, and only visitors are included in tourism statistics.

'International Academy for the Study of Tourism' offers a more complex definition in its Tourism Dictionary: "Tourism is a term denoting travelling for pleasure; activities made available to carry out this type of travel; the industry that fulfills the needs of a tourist. Tourism must encompass the following ideas: a) travelling; b) complete freedom of choice of destination as well as the means of transportation; c) seeking personal pleasure; d) enjoyment, escapism, health needs, exploring, education and culture, etc. are defined as pleasure. Tourism is different from travelling as there is a freedom of choice of the destination and seeking pleasure" (Čomić et al. 2008).

Ćosić (2013: 27) defines tourism from the aspect of tourist demand and offer according to Leiper model of tourism systems. From the aspect of tourism demand, tourism can be conceptually understood as a set of activities carried out by people travelling to and staying outside their place of residence, which is not longer than one consequtive year, for leisure, business and other purposes. According to the same author (2013: 29), the definitions of tourism given from the aspect of tourist offer are practically related to further development of the previous group of definitions and they are based on the method of tourism satellite accounts (TSA) in thier scope and measure of the economic sector of tourism.

Unković and Zečević (2012: 28) offer definition of tourism as an industry according to which 'Tourism is a diversified industry branch consisting of different industrial and nonindustrial activities included together to fulfill the needs of domestic and inbound tourists. The foundations of tourism industry activities include hospitality, transportation, travel agencies, retail shops, crafts and 
other utility services. The following should be stressed among nonindustrial activities: cultural, art, sports and other activities, different tourist organizations and organs at regional, national and international levels, which have both direct and indirect influence on the development of tourist offer. However, a further definition of tourism as industry, i.e. tourism industry, requires considering the activities mentioned in the first set of industrial activities as they form the foundations for tourism industry in a country.

This represents only a small portion of definitions, as only quoting all of them would require a much longer paper. Without aiming at yet another definition, it should be noted that activities within tourism are mainly based on the knowledge of geography, history and history of art in particular, economy, languages and law. We are especially interested in the courses of law in tourism, i.e. legal education of tourism professionals, so we underline the fact that WTO collects legal regulations related to tourism in all its member states to be published in a special newsletter. This contributes to systemization and classification of legal regulations within tourism. All legal regulations are divided into thirteen main groups:

1. Organisation of tourism, 2. Transportation: air, rail, road and sea, 3. Hotel industry, 4. Systematic measures of state assistance and incentives to hotel industry, 5 . Complementary accommodation capacities, 6. Regional planning and development of tourism, 7. Tourist sites and destinations, 8 . Travel agencies, 9. Immigration, customs and other formalities and their simplification in order to increase the number of tourists, 10. Publicity, advertising and public relations, 11. Monument and heritage conservation, 12. Nature preservation, 13. Publications and sets of regulations related to tourism. This classification points to a great diversity of regulations which are under the umbrella of 'tourism legislation'.
Skakun (2013: 13) states numerous definitions which attempt to determine the term 'Law in Tourism'. For instance, H. Klat uses the term 'Tourism Law', R Baretje 'Tourism and Law', and L. Bill 'Law for hotels, restaurants and camps'. Authors from Serbianand Croatian-speaking countries have not reached a full agreement on the definition of legal regulations in tourism. S. Sušić was the furthest in an attempt to found a new legal discipline - Tourism Law. "Tourism Law, in general sense, comprises legal norms regulating legal status of organisations operating in tourism and tourism-legal agreements signed by parties in tourism law”. S. Sušić concludes from this that "... tourism law deals with legal regulations of specific economic relations in tourism". Esteemed professor, R. Đurović considers that “... tourism law, although still not fully formed, is the branch of law with many characteristics and 'tourism legislation' will undoubtedly develop in line with the needs from real life situations". V. Gorenc also starts from the term of tourism law, which he defines as “... the sum of all norms regulating the relations in tourism industry". In addition to tourism legislation, he considers also business customs, general conditions of cooperation, etc. Professor M. Vasiljević implicitly acknowledges tourism law while listing it with other independent disciplines of commercial law: property law, banking law, stock market law, transportation law, cheque law, etc. Without accepting the notion of the independent 'tourism law', I. Antunac points to versatility of normative and administrative jurisdiction in tourism, simultaneously creating the dilemma: "is it law and legislation in tourism or tourism in law and legislation. However, the question is whether such a dilemma is theoretically and scientifically grounded". In the latest edition of the book "Business Law in Tourism and Hospitality Industry”, Vilim Gorenc and Vjekoslav Šmid define tourism as a branch of industry "represented by a set of heterogeneous activities with common 
objective to satisfy the needs of tourists, which makes tourism part of public economy". Based on this definition, the authors do not explicitly mention tourism law, but they underline three main fields requiring special legal treatment: tourist contracts, means of payment and personal identification documents in tourism, and commercial companies as the main components of tourism industry.

\section{Representation of law courses in accredited curricula at higher education institutions in Serbia}

In its development plans, Serbia has denoted tourism as the key branch. One of the objectives of tourism industry in Serbia was annual foreign exchange income of 1000000 000 US dollars. It was reached only in 2013 with 1.053 billion and in 2014 it amounted to 1.139 billion. The number of employees in tourism-related business in 2011 accounted for $3 \%$ of the total emlpoyed in Serbia according to WTTC, while in the total of jobs direclty and indirectly related to tourism it was $6 \%$. According to the same data, tourism generated 32100 job positions and 48 100 positions indirectly linked to tourism.

One of the main factors in doing business in tourism industry (as well as in other branches) is human resources. It seems that it is maybe even the most important in tourism. This often underlines the fact of inadequate education of future tourism professionals. Yugoslavia with 23 million of inhabitants and relatively developed tourism had 11 faculties and colleges that educated tourism professionals. According to the Accreditation and Quality Control Committee, there are eight faculties and colleges of applied sciences educating students to work in tourism in Serbia today. The allowed quota of students enrolling in the first year of studies is 1400 . The curriculum and sylabus depend on whether the faculties and colleges have economic or geographic character. The higher education institutions where economy and tourism are taught mostly offer three groups of courses to students: first group includes Economics of Toursim, Foundations of Economy, Hotel Industry, Travel Agencies, second group consists of Special Interest Tourism, Cultural Heritage and Tourism, Law in Toursim, and the third group includes foreign languages.

The following chapter will attempt to present the situation of law courses through analysis whose objective is to demonstrate the representation of law courses in accredited tourism curricula at higher education institutions in Serbia. Out of 35 couses in three years of undergraduate studies the College of Tourism offers three law courses: Foundations of Law (first year, elective), Business Law (second year, compulsory) and Political and Legal System of the Republic of Serbia (third year, elective). There are two law courses out of the total of 38 courses at the College of Hotel Management: Business Law (first year, compulsory) and EU Legislation in Hotel Industry (third year, elective). Belgrade Business School at the department of Management in Tourism has 31 courses and 2 are law courses: Business Law in Tourism (third year, compulsory) and Business Law in Tourism - Practical (third year, compulsory). Out of 30 courses at the Tourism and Hotel Management of the Business College in Novi Sad, there is one law course: Business Law (first year, compulsory). One law course out of total of 35 studied at the Business College in Blace is called Business Law (second year, compulsory). Out of 36 courses at the department of Tourism and Hospitality Industry of the Business College in Leskovac, there is one law course: Trade Law (second year, compulsory). At the Busniness Techical College in Uzice, at the department of Tourism, there is a total of 25 courses and one law course - Business Law (third year, compulsory). At the College of Technology in Arandjelovac, at the Management in 
Tourism and Hospitality Industry department there are 32 courses but not even one law course. The situation is quite similar at faculties educating future tourism professionals. The Faculty of Economy in Belgrade has the Tourism and Hotel Industry module with 33 courses, out of which one is a law course - International Commercial Law (third year, compulsory).

Out of 44 courses in total studied during four years of undergraduate studies at the Faculty of Natural Sciences and Mathematics in Novi Sad (Tourism module) there is one law course: Law in Tourism (second year, compulsory). At the Faculty of Hotel and Tourism Industry in Vrnjacka Banja 30 courses are studied including two law courses: Tourism Law (fourth year, compulsory) and Consumer Law (fourth year, elective).

Out of 48 courses in total taught for four years of undergraduate studies at the Faculty of Geography in Belgrade, at the department of Tourism, there is one law course, Business Law (fourth year, compulsory). At the Faculty of Agriculture in Novi Sad (department of Agro-tourism and Rural Development) there are 39 courses, out of which one is a law course - Corporate Law in Tourism (second year, compulsory). Out of 36 courses at the Business Management department (Management in Tourism module) at the Faculty of Economy in Nis, one is a law course - Commercial Law (second year, compulsory). Out of 31 courses taught during four years at the Faculty for Tourism and Hotel Management at Singidunum University, there is one law course - Law in Tourism (second year, compulsory). At the Faculty for Sports and Tourism in Novi Sad, out of the total of 38 courses one is a law course: Law and Ethics (second year, compulsory). Some statistics: out of 253 courses taught at colleges with tourism and hotel industry departments only 11 are law courses, which amounts to $4.3 \%$. Out of 299 courses studied at eight faculties in Serbia with departments for tourism and hotel industry law courses is represented by 10 courses or $3.3 \%$

Law courses are usually entitled Corporate (Trade or Commercial) Law, while there is also EU Legislation at the College of Hotel Management in Belgrade and at the Faculty for Tourism and Hotel Industry at Singidunum University. At the College of Tourism in Belgrade, there also Foundations of Law and Political and Legal System of the Republic of Serbia.

Although it would be necessary, it is not possible to conduct the analysis of the textbooks used by students for this research. However, there is an indicator that the syllabi of those courses were tailored according to the lecturing professors, without the real students' needs being taken into consideration. And what are the real needs of students? Why is it necessary for them to understand this subjet matter? Is the knowledge of law a prerequsite for future tourism professionals? How to interpret regulations related to tourism?

It is a common practice of all modern states to regulate the majority of social phenomena and relations by law. The same applies to tourism. The first regulations in this sector were related to activities and services in tourist destinations: nominating the destination, order and cleaniness of the destination, tourist tax, guides and interpreters, renting private accommodation, work hours of retail shops, utility companies, tourist associations, etc. The following regulations were brought in relation to hotel and hospitality industry: design and equipment of hotel facilities, categories of hotels and guest houses, prices of services, checking-in and cheking-out of guests. They are followed by more general regulations: on tourist organisations and bodies, on tasks and aims of tourism development, on protecting of and adding value to natural and cultural heritage, on festivals and events, on tourism advertising, etc. According to the character, those regulations belong to civil, trade, 
administrative, management, crime, international and other branches of law. According to the type, those regulations were also diverse: laws, orders, regulations, guidelines, resolutions and other.

Tourism sector in Serbia has legal foundations in the Constitution of the Republic of Serbia, Law on Economic Entities and Law on Tourism. These acts define the basic principles of organising and operating companies, including companies working in tourism industry. It can be concluded that the legislation has relatively adequately followed and altered the working and developing conditions in tourism sector, but often not at the right moment. Wider integration of legal entities from tourism industry into the European and world tourist offer has two very important conditions: 1. Adopting the Law on Tourism and 2. Adapting norms of the whole tourist operation to the legal standards implemented in the regions of international offer and demand.

Another relevant yet insufficiently represented segment related to tourism education and law in toursim is linked to the rights of disabled people. Tourism professionals must also consider this segment of population due to at least two reasons: their tourist offer should allow disabled persons to travel like everyone else and realise their basic rights, and thus to secure their position on the tourist market. In odrer to prepare for the above mentioned, faculties and colleges should introduce the rights of disabled people into the law courses.

Bearing in mind that there over 80000 000 persons with disabilities in Europe, and that number will keep increasing year after year according to the estimation given by the WHO, the market of acceccible toursim represents huge potential, which has unfortunately been neglected. Accessability of accommodation, facilities, transport, and information have the key role in the development of accessible tourism. At the same time, insufficient awareness and familiarity are the greatest barriers. The countries that have recognized the importance of accessible tourism already have trainings for the employees in order to work with disabled people. Grady and Ohlin (2009) underline the necessity to inform the tourism and hospitality professionals on the disabled persons, i.e. their needs and suggest special trainings for the people working in this sector. For instance, hotel staff should be familiar with all the parts of their hotel in order to recognize potential problems and solve them as soon as possible.

So far, a large number of international legal acts has been adopted from this field and we will list just a few: 'Universal Declaration on the Rights of Man' (1948), 'International Covenant on Civil and Political Rights' (1966), 'International Covenant on Economic, Social and Cultural Rights' (1966). The main idea of those documents is true equality and egality of all people. It became obvious very soon that even though disabled people were given all the rights, they often face obstacles, prejudices, marginalization and discrimination. Therefore, efforts have been made under the auspices of the UN since the second half of the last century to adopt special acts for mplementing the rights of disabled people in practice. The most important document is certainly 'International Convention on the Rights of Persons with Disablities', signed by Serbian government in 2007 and ratified in 2009.

In 1980, 'The Disability Intergroup' was formed in the EU while in 1996 the 'The High Level Goup on Disability' was founded. The groups deal with socio-economic, employment and educational issues related to persons with disabilities. Travel and tourism represent the recognized social right of all citizens in the EU, which is not available partially or fully to persons with disabilities.

Apart from accepting the mentioned international conventions, Serbia adopted the Law on Preventing Discrimination against Disabled People on 17 April 2006. The law 
is based on the principles: prohibition of discrimination against persons with disabilities; respecting human rights and dignities of persons with disabilities; inclusion of persons with disabilities in all spheres of life based on equality; inclusion of persons with disabilites in all decision-making related to their rights and obligations.

The development of tourism in the world, especially intentions explained in the economic and development policy of Serbia, clearly show the determination to improve tourist offer in the country. This requires wider education in tourism in any sense, including familiarity with the rights of disabled people.

\section{Conclusion}

Based on the presented data, the following can be concluded:

State organs of the Republic of Serbia do not have a consistent policy of education and employment in tourism sector. This is reflected mainly in unrealistic decision related to the number of students enrolling the first year of all studies, including tourism.

The process of accreditation of higher education institutions and curiculla is burdened by the fulfillment of formal requirements, which has lead to a massive number of faculties and colleges educating students for tourism industry. Law courses are inadequately represented in accredited curricula at faculties and colleges with the total of only $3.8 \%$.

It is absolutely certain that students of tourism need to be offered a possiblity to acquire knowledge in specific legal disciplines, e.g.: disabled people rights, customer protection, special insurance in tourism, etc. It is possible that one of the first steps in this direction would be a definition (given by an expert body) of the minimum curriculum of law courses for all institutions offering tourism education.

\section{References}

Blagojević S. (2010) Turizam ekonomska osnova i organizacijski sistem, Grafo-press d.o.o., Novi Sad.

Čomić Đ., Jović G., Popović I., (2008) Osnove turizma, Filozofski fakultet Univerzitet u Istčnom Sarajevu, Pale.

Ćosić M. (2013) Ekonomski aspekti turizma, Visoka turistička škola, Beograd.

Grady J., Ohlin J. (2009) Equal access to hospitality services for guests with mobility impairments under the Americans with Disabilities Act: implications for the hospitality industry, International Journal of Hospitality Management, 28(1), str. 161-169.

Konkurs za upis studenata u prvu godinu osnovnih i integrisanih studija na visokoškolskim ustanovama čiji osnivač Republika za školsku 2014/2015.godinu, Prosvetni pregled, Beograd.

Skakun M., Skakun U., (2012) Osnovi prava u turizmu, Visoka turistička škola, Beograd

Skakun M., Skakun U., (2013) Poslovno pravo u turizmu, Visoka turistička škola, Beograd.

Tatić D. (2008) Zaštita ljudskih prava osoba sa invaliditetom, Udruženje distrofičara, Službeni glasnik, Beograd.

Unković S., Zečević B., (2012) Ekonomika turizma, Centar za izdavačku delatnost Ekonomskog fakulteta u Beogradu, Beograd.

Vukonić B. (2010) Budućnost mnogih iluzija, Visoka poslovna škola za turistički i hotelski menadžment Utilus, Zagreb.

www.bbs.edu.rs

www.dgt.uns.ac.rs

www.eknfak.ni.ac.rs

www.ekof.bg.ac.rs

www.fthm.singidunum.ac.rs

www.gef.bg.ac.rs

www.hit-vb.kg.ac.rs

www.polj.uns.ac.rs

www.tims.edu.rs

www.vhs.edu.rs

www.visokaturisticka.edu.rs 
www.vps.ns.ac.rs

www.vpskp.edu.rs

www.vpsle.edu.rs

www.vpts.edu.rs

www.vtsar.edu.rs 